\title{
Benefits of Nigella sativa Extract Protecting Ovary Due to Cisplatin Chemotherapy
}

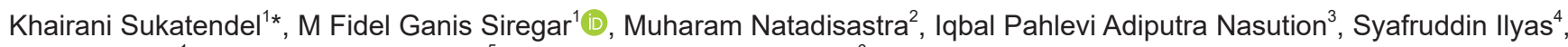
M. Rhiza Tala ${ }^{1}$, Putri Chairani Eyanoer ${ }^{5}$, Poppy Anjelisa Z. Hasibuan ${ }^{6}$

${ }^{1}$ Department of Obstetrics and Gynecology, Faculty of Medicine, University Sumatera Utara, Medan, Indonesia; ${ }^{2}$ Department of Obstetrics and Gynecology, Faculty of Medicine, University Indonesia, Jakarta, Indonesia; ${ }^{3}$ Doctoral Program, Faculty of Medicine, University Sumatera Utara, Medan, Indonesia; ${ }^{4}$ Department of Biology, Faculty of Science, University Sumatera Utara, Medan, Indonesia; ${ }^{5}$ Department of Community Medicine, Public Health, Faculty of Medicine, University Sumatera Utara, Medan, Indonesia; ${ }^{6}$ Department of Pharmacology, Faculty of Pharmacy, University Sumatera Utara, Medan, Indonesia

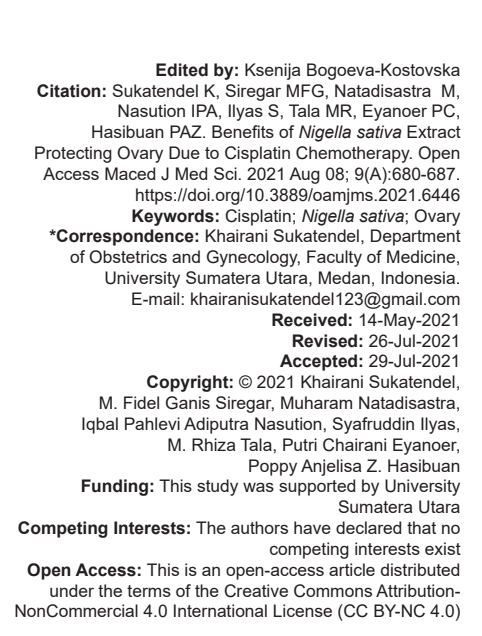

\section{Abstract}

BACKGROUND: Cisplatin (CIS) is an important chemotherapy agent which is widely used for the treatment of many types of solid tumors, which can cause decreased ovarian function. Nigella sativa has been shown to have an antiinflammatory and anti-oxidant activity that might protect the ovaries from damage due to $\mathrm{CIS}$.

AIM: This study aims to understand the benefits of $\mathrm{N}$. sativa protecting the ovaries due to CIS chemotherapy.

METHODS: Thirty-two female Rattus norvegicus aged 8 weeks weighing 160-200 g were divided into four groups: Negative control, Positive control, Treatment-1 (CIS 6 mg/KgBW and NS $500 \mathrm{mg} / \mathrm{KgBW} /$ day), and Treatment-2 (CIS $6 \mathrm{mg} / \mathrm{KgBW}$ and NS $1000 \mathrm{mg} / \mathrm{kgBW} /$ day) for 2 weeks. On the $14^{\text {th }}$ day the rats were sacrificed, blood was drawn from the heart, followed by taking ovaries.

RESULTS: There was lower mortality and morbidity in CIS + NS 1000 and CIS + NS 500 mg group $(p=0.01$ and 0.001). The mean estradiol levels, follicle-stimulating hormone levels, and anti-mullerian hormone levels were not statistically significant among the four groups. The highest number of primary, secondary, tertiary follicles are seen at the CIS + NS $500 \mathrm{mg}$ and CIS + NS $1000 \mathrm{mg}$ groups $(p=0.05)$. The lowest number of atretic follicles is seen at the CIS + NS $1000 \mathrm{mg}$ group, and the highest number of atretic follicles was in CIS only.

CONCLUSION: There is a trend that $N$. sativa is beneficial in protecting the ovaries from damage caused by CIS

\section{Introduction}

Artificial or acquired ovarian function decline, among others, occur in cancer patients treated with radiation and chemotherapy. According to Globocan in 2018, there were 18.1 million new cases with a death rate of 9.6 million, where one in five men and one in six women in the world experience cancer [1]. Top five female cancers in Indonesia: Breast 65,858 (30.8\%), cervix. 36,633 (17.2\%), Ovary 14,896 (7\%), Colorectum 12,425 (5.8\%), and Thyroid 9,053 (4.2\%) [2].

The survival of women with various types of cancer has improved significantly with improvements in cancer treatment, including early detection and effective management [3]. The American Cancer Society reports in Cancer Facts and Figures, that the 5-year relative survival for all cancers has increased substantially since the early 1960 s, from $39 \%$ to $70 \%$ among whites and from $27 \%$ to $63 \%$ among blacks.
Increased survival of women with cancer who need quality of life care, which preserves their fertility. Cisplatin (CIS) and Paclitaxel are the most widely used chemotherapeutic agents for the treatment of gynecological malignancies, and their mode of action against ovarian cancer cells has been thoroughly investigated. CIS interferes with DNA replication and kills the fastest-growing cells [4]. The effects of cancer and its treatment on female reproductive function are increasingly well documented. Overall, compared to the general population, women were $38 \%$ less likely to become pregnant after diagnosis and undergoing cancer treatment, in all cancer diagnostic groups being associated with a decreased likelihood of subsequent pregnancies [5]. Given this situation, there is now an urgent need to develop methods to protect the ovaries from the deleterious effects of treatment, thereby reducing the risk of decreased fertility and premature menopause. CIS-induced ovarian damage has been found in studies of the culture of cortical pieces of 
human ovaries or granulosa cells, found a decrease in the number of follicles and a reduction in steroidogenic activity [6], [7].

There is a lot of evidence showing the loss of ovarian reserves and increased follicular atresia after exposure to CIS in the ovaries of rats and mice [7], [8], [9], [10], [11], [12], CIS is an anti-drug. cancers that cause ovarian damage in a moderate category [13].

Chemotherapy and radiation agents have been shown to induce oxidative stress and inflammation. Four different antioxidants, Mesna, Mirtazapine, Resveratrol, and Sildenafil citrate, have been tested for their protective effect on ovarian reserves of CIS-treated mice [14], [15], [16]. Mesna, Sildenafil citrate, and Resveratrol prevent antimullerian hormone (AMH)-positive follicle loss; Mirtazapine also increases fertility. The enzymatic antioxidant activity of superoxide dismutase (SOD) and glutathione increased after administration of Mesna or Mirtazapine with CIS.

Assi et al. (2018) reported, giving Nigella sativa to experimental mice that experienced a decrease in ovarian function due to lead acetate showed a significant increase in ovarian function compared to controls. $N$. sativa containing thymoquinone (TQ) monoterpene has been shown to exhibit strong antioxidant properties and a protective effect against oxidative damage caused by some drugs and toxins. CIS treatment causes an oxidant/antioxidant imbalance which is reflected in an increase in lipid peroxidation, a decrease in enzymatic and non-enzymatic antioxidants [17].

Seeing the results of previous research on the benefits of $N$. sativa in improving ovarian function, and seeing the ovarian damage caused by chemotherapy, it is necessary to conduct research on the benefits of $N$. sativa containing TQ to protect ovarian function in women undergoing chemotherapy, starting with research on experimental mice.

\section{Methods}

\section{Research type and location}

This experimental animal research was carried out at the Animal Laboratory of the Faculty of Mathematics and Natural Sciences Sumatera Utara University. Estradiol, $\mathrm{AMH}$, and follicle-stimulating hormone (FSH) level examination of ovaries was carried out at at the Integrated Laboratory of Faculty of Medicine, Sumatra Utara University.

Histological examination of the ovary was carried out at the Department of Anatomical Pathology, Faculty of Medicine, Sumatra Utara University.

\section{Material}

1. $\quad N$. sativa seed extract in the form of oil, brand Habbasy $500 \mathrm{mg}$ and $1000 \mathrm{mg}$

2. CIS

3. Ovary

4. Blood.

\section{Experimental animal}

The protocol of the study was approved by the Animal research ethics committee of the Faculty of Mathematics and Natural Sciences Sumatera Utara University with reference number of 00714/ KEPH-FMIPA/2020 in accordance to "Guide for care and use of laboratory animals" set by the Faculty of Mathematics and Natural Sciences, University Sumatera Utara.

Thirty-two female laboratory rats (Rattus norvegicus) aged 8 weeks weighing 160-200 g were used in this study, according to Federer's formula (1963), Rats were acclimatized for 7 days, given food and drink ad libitum. They were placed in a cage in a room with a temperature of $22-25^{\circ} \mathrm{C}$ with a light-dark cycle of $12 / 12 \mathrm{~h}$. Wistar rats were divided into 4 groups:

(1) $\mathrm{C} 1$ = Negative control (rats were not given CIS).

(2) $\mathrm{C} 2$ = Positive control (rats were given an injection of single dose CIS $6 \mathrm{mg} / \mathrm{kgBW}$ intraperitoneally only).

(3) T1 = Treatment 1 (rats were given a single dose of CIS $6 \mathrm{mg} / \mathrm{KgBW}$ intraperitoneal and NS $500 \mathrm{mg} / \mathrm{KgBW} /$ day). (4) T2 = Treatment 2 (rats were given a single dose of CIS $6 \mathrm{mg} / \mathrm{KgBW}$ intraperitoneally and NS $1000 \mathrm{mg} /$ $\mathrm{kgBW} /$ day) for 2 weeks. On the $14^{\text {th }}$ day the rats were sacrificed, blood was drawn from the heart, followed by taking ovaries.

\section{Blood collection}

Prior to blood sampling, the rats were anesthetized with diethyl ether to ease handling. The blood samples were collected by cardiac puncture using 25G, 1" needle. Approximately 2-3 ml of blood samples were taken and dispensed into labeled plain tubes. The blood samples were then centrifuged at 3000 rpm for $10 \mathrm{~min}$ to separate the sera. The serum was stored at $-80^{\circ} \mathrm{C}$ until further use.

\section{Ovarium histological study}

The ovary was removed and freed from all connective tissue prior to wet weight recordings. Routine histological processes were employed and each ovary was cut. Each portion was prepared as a block and randomly chosen and examined under a light microscope (Olympus CK2) for primary, secondary, tertiary, and atretic follicles. Appropriate image capture was done using a light microscope (Olympus CK2) coupled to a camera (Olympus BX 41). 


\section{Chemicals and reagents}

Estradiol, $\mathrm{FSH}$, and $\mathrm{AMH}$ levels were examined by enzyme-linked immunosorbent assay (ELISA), using rat Estradiol ELISA Kit, 96T rat reagent, rat FSH ELISA Kit 96T, and rat AMH ELISA Kit 96T from Elabsciennce. Histopathological examination was carried out by using Hematoxylin Eosin staining.

\section{Statistical analysis}

To assess whether the sample is normally distributed or not, the Shapiro-Wilk test is carried out because the sample is $<50$. Data are presented in the form of mean standard deviation To assess the comparison of parameters between the control group and the treatment group, the One Way analysis of variance (ANOVA) and Kruskal's Wallis test analysis were used. Data were processed and analyzed using SPSS with a significance limit of $p<0.05$.

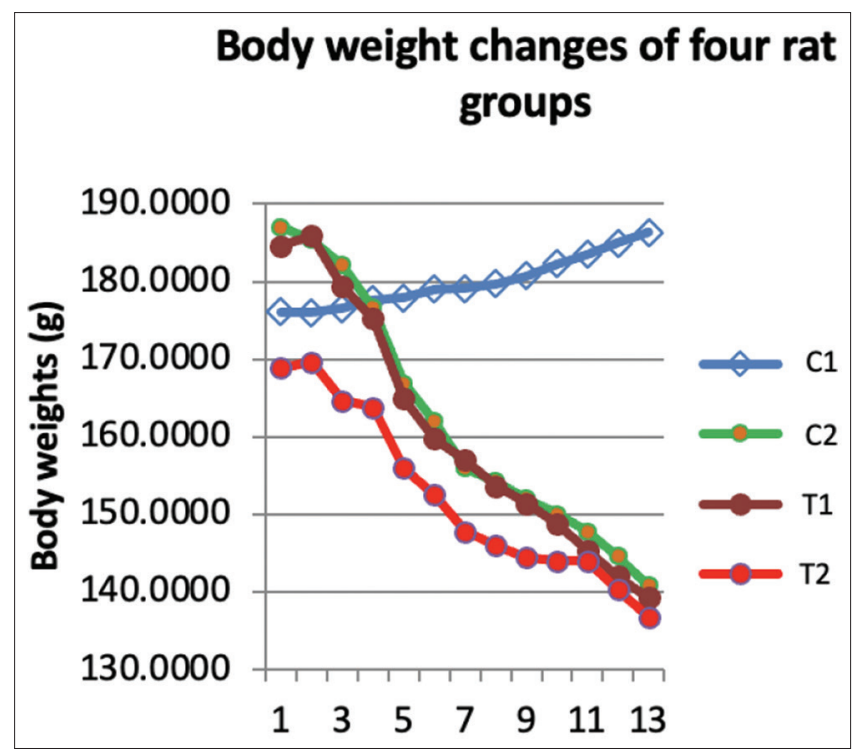

Figure 1: Comparison of mean body weight before and after intervention in 4 groups

\section{Results}

\section{Mortality and morbidity}

There were $4(50 \%)$ deaths of rats in the CIS group, 2 rats died on the $7^{\text {th }}$ day and 2 on the $8^{\text {th }}$ day. In CIS + NS 500 mg, 2 dead rats (25\%), both of which died on the $9^{\text {th }}$ day. There were no rat that died in the Negative Control and CIS + NS $1000 \mathrm{mg}$ group ( $p=0.01,<0.05)$ Four rats that died in the CIS group and 2 in the CIS + NS 500 mg group were then replaced with other rats and given the appropriate treatment. There were no health problems that occurred in the negative control group rats, while the positive control group that received CIS all experienced morbidity of diarrhea, nosebleeds, and eyesores (100\%). The rats in the CIS + NS $500 \mathrm{mg}$ group and CIS + NS 1000 mg) had diarrhea, nosebleeds, eyesores as much as $50 \%$ and $25 \%$, respectively. The morbidity score differences in four groups of study was significant statistically ( $p=0.001, p<0.05)$.

Results of weight assessment before treatment and 14 days after treatment showed a significant reduction in body weight $(p<0.05)$ (Figure 1$)$. This weight loss was due to the effects of CIS chemotherapy, while the Negative control group who did not receive $\mathrm{CIS}$ gained weight.

\section{Estradiol, FSH, and AMH levels}

The lowest mean level of estradiol was found in the CIS group, namely $66.97 \pm 20.45 \mathrm{pg} / \mathrm{ml}$, the highest mean level was found in the CIS + NS 1000 group, namely $114.53 \pm 35.33 \mathrm{pg} / \mathrm{ml}$. There was a decrease in Estradiol levels in the CIS group compared to Negative Control and an increase in Estradiol levels in the CIS + NS 500 and CIS + NS 1000 groups compared to CIS only, $(p=0.069, p>0.05)$, meaning that statistically there was no significant difference (Figure 2).

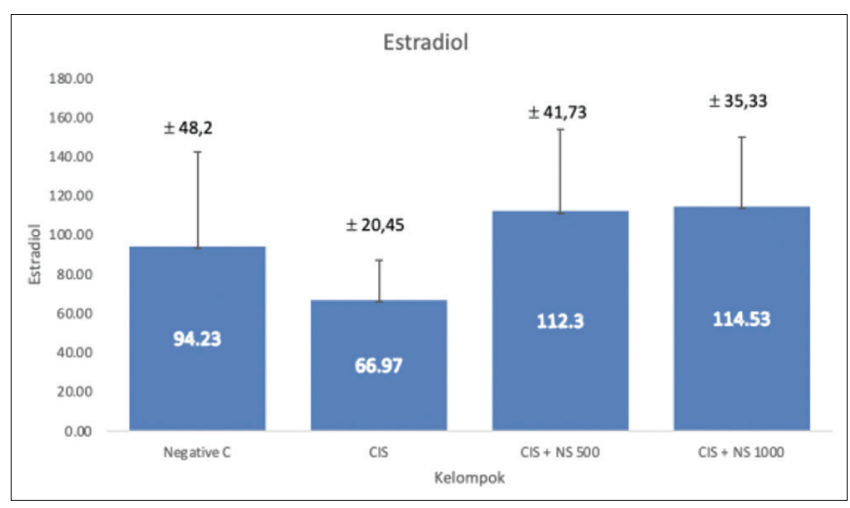

Figure 2: Diagram of mean and standard deviation of Estradiol levels ANOVA, $p=0.06$

The lowest mean of FSH levels was in the Negative control group, namely $19.49 \pm 2.64$, the highest mean level was in the CIS + NS 500 groups, namely, 21.68 $\pm 0.92 \mathrm{ng} / \mathrm{l}$. There was an increase in FSH levels in the $\mathrm{CIS}$ group compared to Negative control, and a decrease in FSH levels in the CIS + NS 1000 group compared to CIS, but the value of $p=0.069(p>0.05)$, meaning that statistically there was no significant difference (Figure 3 ).

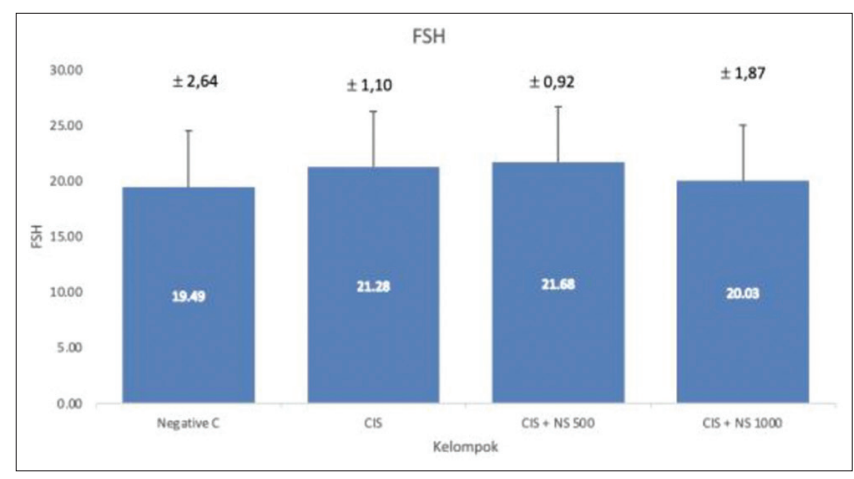

Figure 3: Diagram of mean and standard deviation of folliclestimulating hormone levels ANOVA, $p=0.06$ 
The lowest mean AMH levels were in the CIS group, namely $3.63 \pm 2.11 \mathrm{ng} / \mathrm{ml}$, the highest mean levels were in the Negative control group, namely, 4.54 \pm 3.53. Statistical tests with ANOVA, the $p$-value was 0.932 ( $p>0.05)$, meaning that there was no statistically significant difference (Figure 4).

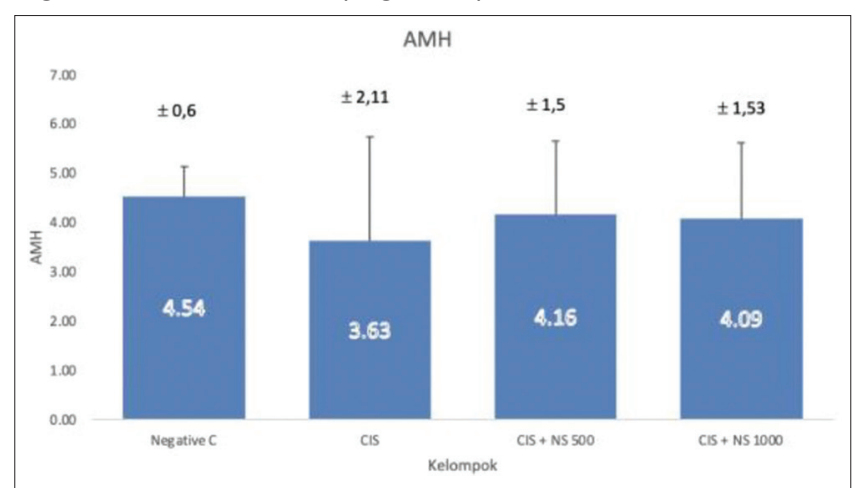

Figure 4: Mean and standard deviation of anti-mullerian hormone levels

ANOVA, $p=0.93$

Because there were no significant differences in the levels of estradiol, $\mathrm{FSH}$, and $\mathrm{AMH}$, to see the superiority between the treatment groups, it could be seen the difference in the value of each treatment group against the positive control (Table 1).

Table 1: Comparison of the difference in levels of Estradiol, $\mathrm{FSH}$, and AMH to CIS only group

\begin{tabular}{lcccccc}
\hline Group & $\mathrm{C} 1$ & $\mathrm{C} 2$ & $\mathrm{~T} 1$ & $\mathrm{~T} 2$ & $\Delta \mathrm{D}$ T1-C2 & $\Delta \mathrm{D}$ T2-C2 \\
\hline Estradiol $(\mathrm{pg} / \mathrm{ml})$ & 94.23 & 66.05 & 112.30 & 114.53 & 46.25 & 48.48 \\
FSH $(\mathrm{ng} / \mathrm{ml})$ & 19.49 & 21.28 & 21.68 & 20.03 & 0.4 & -1.25 \\
AMH (pg/ml) & 4.54 & 3.63 & 4.16 & 4.09 & 0.53 & 0.46 \\
\hline FSH: Follicle-stimulating hormone, AMH: Anti-mullerian hormone, CIS: Cisplatin.
\end{tabular}

It can be seen that in the CIS + NS 500 and P CIS + NS 1000 groups, the mean levels of estradiol are higher than those of CIS only without NS, with a difference of an increase of $46.25 \mathrm{pg} / \mathrm{l}$ and $48.48 \mathrm{pg} / \mathrm{l}$, it appears that $\mathrm{CIS}+\mathrm{NS} 1000$ is slightly superior to CIS + NS 500 . This is in line with the lower in FSH levels in the CIS + NS 1000 group compared to CIS only and higher $\mathrm{AMH}$ levels in the CIS + NS 500 and CIS + NS 1000 groups

Table 2: Comparison of the difference in primary, secundary, tertiary, and atresia follicles count to CIS only group

\begin{tabular}{lcccccc}
\hline Group & $\mathrm{C} 1$ & $\mathrm{C} 2$ & $\mathrm{~T} 1$ & $\mathrm{~T} 2$ & $\Delta \mathrm{D} \mathrm{C} 2-\mathrm{T} 1$ & $\Delta \mathrm{D}$ C2-T2 \\
\hline $\begin{array}{l}\text { Primary, secundary, } \\
\text { tertiary, follicles }\end{array}$ & 6.87 & 7.37 & 16.62 & 31.50 & 9.25 & 24.25 \\
Atresia follices & 23.0 & 44.62 & 33.37 & 16.87 & -11.25 & -27.75 \\
\hline
\end{tabular}

Atresia follices .CIS: Cisplatin.

\section{Ovarian histopathology examination results}

Results of the histopathology examination are shown in (Figures 5-8, and Table 2).

\section{Discussion}

The cause of death in four mice that received $\mathrm{CIS}$ alone and two mice in the CIS + NS 500 mg group, is not known with certainly, it should be suspected that death was due to the toxic effects of CIS on organs and serious gastrointestinal disorders such as severe diarrhea, nausea, vomiting, and reduction appetite and dehydrated. The majority of morbidity in this study was diarrhea $(75 \%)$.

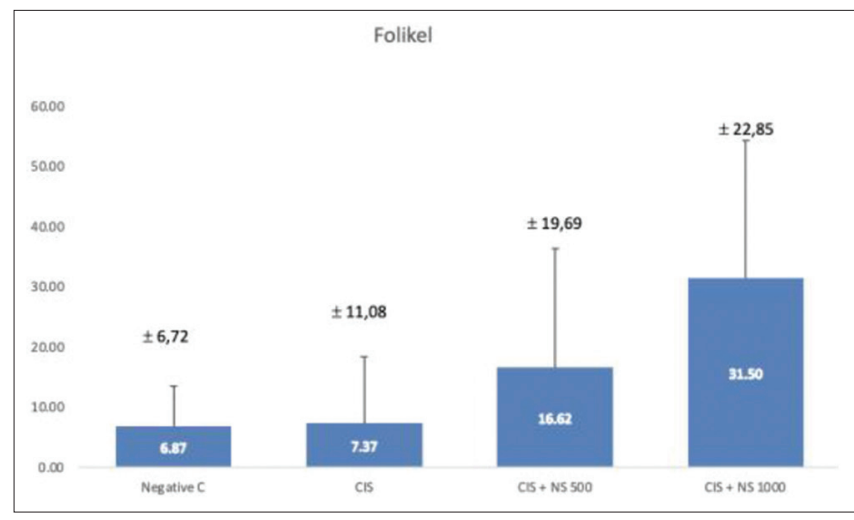

Figure 5: Mean and standard deviation of primary, secondary, tertiary follicle count

Kruskal Wallis, $p=0.05$

Based on the results of this study, giving $N$. sativa seems to reduce mortality and morbidity of mice due to CIS, but does not prevent weight loss. Weight loss was found in all animal groups $(p<0.05)$. This seems to be related to the side effects of CIS. Aldossary (2013) reported the results of his study on 123 patients with 11 types of tumors that the majority of patients $(72 \%)$ experienced gastrointestinal disorders, such as nausea and vomiting, diarrhea, constipation, epigastralgia, pyrosis, dysphasia, postprandial abdominal bloating sensation, tongue white, dysgeusia and taste disorders. Among other side effects, constitutional symptoms include hypostenia and asthenia, fever, weight loss, and decreased appetite. Nausea and vomiting are considered to be the most common types of CIS poisoning during chemotherapy. One study examining the toxicity of CIS after a dose of $120 \mathrm{mg} / \mathrm{m}^{2}$ found that patients who did not receive antiemetic drugs prior to CIS had an average of 11 episodes of emetics [18]. The presence of this prolonged nausea and vomiting, coupled with diarrhea may be associated with decreased appetite, and ultimately lead to weight loss.

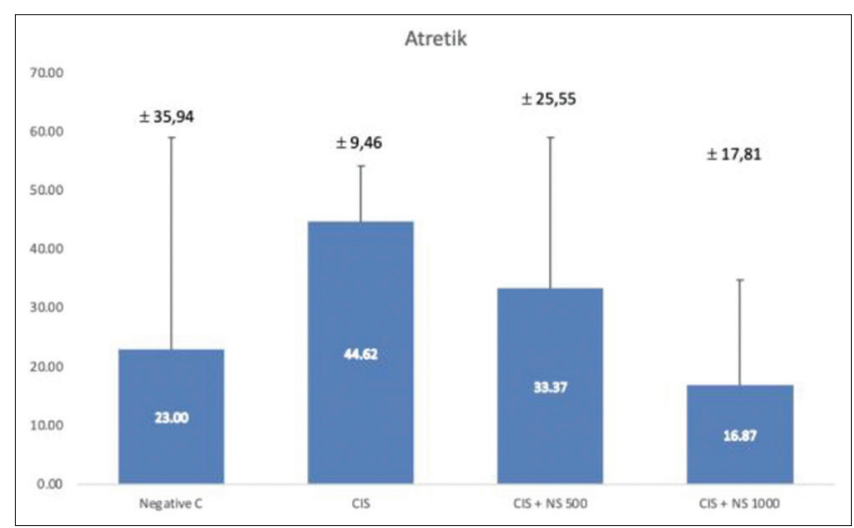

Figure 6: Mean and standard deviation of atresia follicle count Kruskal Wallis, $p=0.31$ 
Cachexia, an accidental weight loss of $\geq 5 \%$, can occur as a serious and dose-limiting chemotherapy side effect that decreases the survival of cancer patients. Changes in lipid metabolism are thought to cause the lipodystrophy commonly associated with cachexia. Ghrelin has been proposed to correct changes in lipid metabolism due to its orthogenic and anabolic properties. There are studies showing the effects of CIS and Ghrelin on lipogenesis, but not on lipolysis and $\beta$ oxidation. Thus, Ghrelin prevents CIS-induced weight and fat loss by restoring adipose tissue function. The increase in calorie intake further increases the anabolic effect of Ghrelin [19].

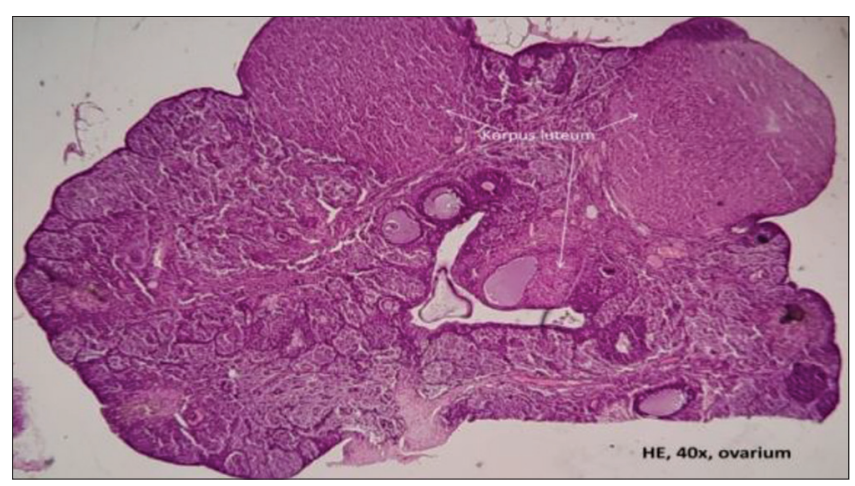

Figure 7: Ovary at 40× magnification

The results of this study showed that statistically there was no significant difference in the levels of estradiol, $\mathrm{FSH}$, and $\mathrm{AMH}$ in the four study groups, so to know the benefits of $N$. sativa and to see the advantages between treatment groups can be seen the difference in value from each treatment group to the positive control. The lowest mean of estradiol levels was found in the CIS group, namely $66.05 \pm 20.45 \mathrm{pg} / \mathrm{ml}$, while the mean estradiol levels in the negative control group were $94.23 \pm 48.20 \mathrm{pg} / \mathrm{ml}$. There was a decrease in the mean of estradiol levels by $28.28 \mathrm{pg} / \mathrm{ml}$ from the normal value, meaning that there was suppression of ovarian function in the rats receiving CIS $6 \mathrm{mg}$ intraperitoneally. There was an increase in estradiol levels in the CIS + NS 500 and CIS + NS 1000 mg groups compared to the CIS group, namely, $112.30 \pm 41.73 \mathrm{pg} / \mathrm{ml}$ and $114.53 \pm 35.33 \mathrm{pg} / \mathrm{ml}$ with a difference of $46.25 \mathrm{pg} / \mathrm{l}$ and $48.48 \mathrm{pg} / \mathrm{l}$. The increase in the mean of Estradiol in the $\mathrm{CIS}+\mathrm{NS} 500 \mathrm{mg}$ and CIS + NS $1000 \mathrm{mg}$ groups even exceeded the normal Estradiol values as found in the Negative control group, namely $94.23 \pm 48.20 \mathrm{pg} / \mathrm{ml}$, this means that the administration of $N$. sativa at a dose of $500 \mathrm{mg} / \mathrm{KgBB}$ and $1000 \mathrm{mg} / \mathrm{KgBB}$ po/days able to prevent mouse ovarian suppression due to receiving CIS $6 \mathrm{~g} / \mathrm{kgBW}$ intraperitoneally. The administration of $N$. sativa at a dose of $1000 \mathrm{mg} / \mathrm{KgBW}$ is better than the dose of $500 \mathrm{mg} / \mathrm{KgBB}$.

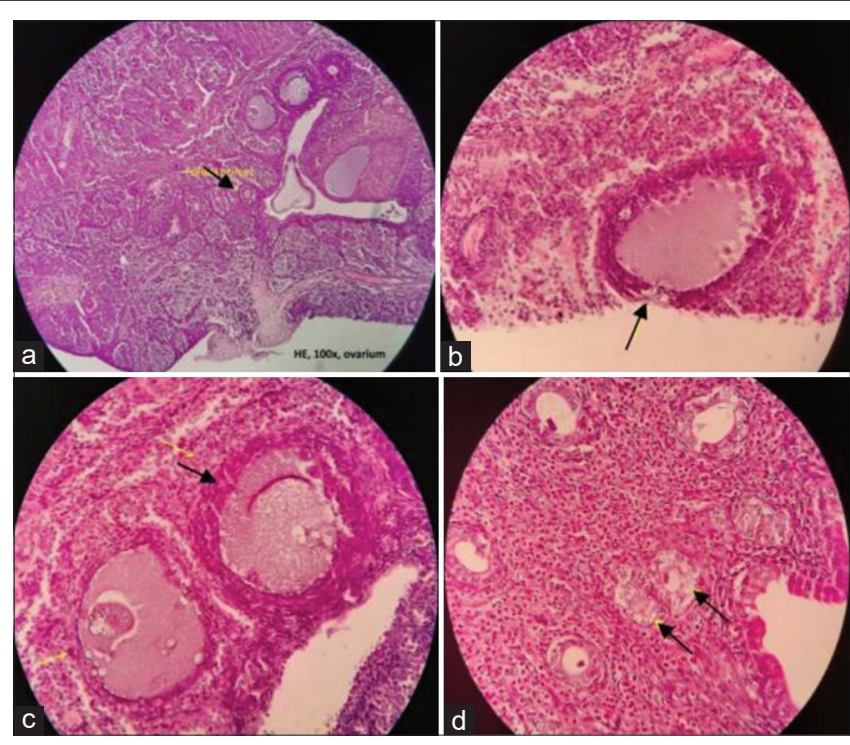

Figure 8: Primary, secondary, tertiary, and atretic follicles of Rattus norvegicus (a) Primary follicle, magnification 100; (b) Secondary follicle, magnification 400x; (c) Tertiary follicle, magnification 400x, (d) Atretic follicle, magnification 400x)

The mean FSH levels increased in the CIS group, namely $21.28 \pm 1.11 \mathrm{ng} / \mathrm{l}$, while the mean FSH levels in the Negative control group were 19.49 $\pm 2.64 \mathrm{ng} / \mathrm{l}$. There was an increase in the mean FSH level of $1.78 \mathrm{ng} / \mathrm{l}$ from the normal value. The increase in $\mathrm{FSH}$ levels is a response from the hypothalamus and pituitary caused by low levels of estradiol produced in the ovaries, which is referred to as negative feedback. This means that there is suppression of ovarian function in rats receiving CIS $6 \mathrm{mg} / \mathrm{KgBW}$ intraperitoneally. There was a decrease in FSH levels in the CIS + NS 1000 group but not in CIS + NS 500 compared to the Negative control, namely, $20.05 \pm 1.87 \mathrm{ng} / \mathrm{ml}$ with a decrease difference of $1.23 \mathrm{ng} / \mathrm{ml}$ which is almost close to the normal value. This means that giving $N$. sativa at a dose of $1000 \mathrm{mg} / \mathrm{KgBB}$ po/day is useful for preventing ovarian suppression of rats due to receiving CIS $6 \mathrm{mg} /$ $\mathrm{KgBB}$ intraperitoneally.

The lowest mean of AMH levels was found in the CIS group, namely, $3.63 \pm 2.11 \mathrm{ng} / \mathrm{ml}$, while in the Negative control group was $4.54 \pm 0.60 \mathrm{ng} / \mathrm{ml}$. There was a decrease in the mean AMH level of $0.91 \mathrm{ng} /$ $\mathrm{ml}$ from the normal value of $\mathrm{AMH}$. A decrease in $\mathrm{AMH}$ levels, although not statistically significant, indicated that there was a suppression of ovarian function in mice receiving CIS $6 \mathrm{mg} / \mathrm{kg}$ intraperitoneally.

Abdulah et al. (2014) reported that there was a significant decrease in the median serum level of $\mathrm{AMH}$ and Inhibin $\mathrm{B}$ patients between before and after Paclitaxel-CIS chemotherapy [20]. There was a decrease in the median $\mathrm{AMH}$ value from $2.54 \mathrm{ng} / \mathrm{ml}$ to $1.99 \mathrm{ng} / \mathrm{ml}$ after the first chemo $(\mathrm{p}=0.01)$, to $1.49 \mathrm{ng} /$ $\mathrm{ml}$ after the second chemo $(\mathrm{p}=0.001)$, and to $1,37 \mathrm{ng} /$ $\mathrm{ml}$ after the third chemo $(p=0.000, p<0.05)$. Likewise, the median decrease in serum $\mathrm{AMH}$ and Inhibin $\mathrm{B}$ levels after Paclitaxel-CIS chemotherapy in each chemotherapy series $p=0.000(p<0.05)$. Conclusion: 
$\mathrm{AMH}$ and inhibin B serum levels in cervical cancer patients who received combination chemotherapy decreased dramatically after 3 months of chemotherapy and the factor that contributed to the decrease was age.

It was found that the number of primary, secondary, tertiary follicles was higher in the CIS + NS 500 and CIS + NS 1000 groups, namely, $16.625 \pm 19.697$ and $31.5 \pm 22.859$ compared to the Negative control and CIS group, namely, $6.875 \pm 6.728$ and $7.375 \pm 11.083$ with a difference of 9.25 and 24.25 , where the largest difference is in CIS + NS $1000(p=0.05)$.

This is in line with the low average number of atretic follicles in the CIS + NS 500, namely $16.87 \pm 17.81$, and CIS + NS 1000 (33.37 \pm 24.55) compared to CIS group (44.62 \pm 9.46$)$ and there are the difference -27.75 and -11.25 to CIS group. Based on the delta of the difference in the mean number of primary, secondary, tertiary, and atretic follicles, CIS + NS 1000 is superior to CIS + NS 500. This suggests that $N$. sativa is beneficial to prevent decline and even improve ovarian function in rats given the chemotherapy drug CIS.

In this study, the decrease in estradiol and $\mathrm{AMH}$ levels was not as large as in other studies, possibly because the dose of CIS used in this study was single dose of $6 \mathrm{mg} / \mathrm{KgBW}$, and the assessment of ovarian function was carried out after 14 days, while in other studies using a dose of $7.5 \mathrm{mg} / \mathrm{KgBB}$ and $5 \mathrm{mg} / \mathrm{KgBB} 2 \times$ with intervals of 5-7 days and assessment of ovarian function is carried out in 7-10 days.

CIS-induced ovarian damage has been found in studies of the culture of cortical pieces of human ovaries or granulosa cells, found a decrease in the number of follicles and a reduction in steroidogenic activity [6], [7]. There is evidence showing a loss of ovarian reserve and an increase in follicular atresia after exposure to CIS in the ovaries of mice and mice [7], [8], [9], [10], [11], [12], immature oocytes are very vulnerable [9], [10]. Studies examining the effects of CIS exposure on the follicle often report loss of PMF, through direct and or indirect death of PMF due to accelerated activation, ultimately leading to premature ovarian insufficiency [21].

Four different antioxidants, Mesna, Mirtazapine, Resveratrol, and Sildenafil citrate, have been tested for their protective effect on the ovarian reserve of CIStreated mice [14], [15], [16]. Mesna, Sildenafil Citrate, and Resveratrol prevent $\mathrm{AMH}$-positive follicle loss; Mirtazapine also increases fertility. The enzymatic antioxidant activity of SOD and Glutathione increased after administration of Mesna or Mirtazapine with CIS. These results indicate that keeping free radicals low in the ovaries is important for increasing the survival of ovarian reserves. Almost all journals report research results that CIS destroys granulosa cells by the occurrence of oxidative stress which depletes ovarian reserves and some products can protect ovarian reserves through anti-oxidation.
$N$. sativa has been shown to have strong antioxidant properties. This potent anti-oxidant activity is reflected in the strong free radical scavenging action against superoxide anions and enhancing transcription genes responsible for the production of natural antioxidants such as SOD, Cathalase, and Glutathione peroxidase [22]

$N$. sativa used in this study is Habbasyi Oil which contains $N$. sativa extract in the form of $500 \mathrm{mg}$ oil in each capsule. The results of the phytochemical laboratory test showed that Habbasyoil contained TQ.

Apart from the antioxidant activity that can protect the ovaries, Mohammed (2013) found estrogen (ER)-like activity of $N$. sativa extract in female mice, which is assumed to stimulate follicle development and the formation of corpora lutea. Female rats treated with $N$. sativa extract showed an increase in the total concentration of serum protein and the hormone progesterone [23]. Apart from TQ, N. sativa also contains saponins which can accelerate the formation of new blood vessels in the wound healing process (angiogenesis) through VEGF. Zinc or zinc in N. sativa is also needed in healing ovarian damage due to CIS [24].

Based on the results of the analysis of Estradiol, $\mathrm{FSH}, \mathrm{AMH}$, and the number of antral ovarian follicles in this study, this study showed a tendency to protect the ovaries from damage due to chemotherapy CIS by $N$. sativa without reducing the anticancer effectiveness of $\mathrm{CIS}$. There is a great deal of research on TQ, alone or in combination with other major chemotherapy agents, which can significantly inhibit cancer progression and synergistically reduce the tumor burden on various malignancies through alteration of multiple tumorigenic pathways.

Ganji-Harsini et al. (2016) conducted an in vitro study on breast cancer cells reported that treatment with a combination of tamoxifen (TAM) and TQ significantly decreased cell viability compared to TAM alone [25]. The apoptotic index increased significantly in the TQ $150 \mu \mathrm{M}(\mathrm{p}<0.05)$, TAM $(\mathrm{p}<0.01)$, TQ $150 \mu \mathrm{M}+$ TAM $(p<0.001)$ groups compared to the control group. The synergistic effect of TQ and TAM agents on ER + and ER cells suggests that TQ functions via an ER-independent pathway. Investigations revealed that TAM induces apoptosis in ER + cells via a nitric oxide-dependent pathway. The use of high doses of $\mathrm{TQ}$ can reduce the dose of TAM and the duration of administration in the treatment of ER + and ER breast cancer cells. Since the number of necrotic cells did not increase in the TQ-treated group, it is safe and harmless for the treatment of resistant metastatic breast cancer patients.

Based on in vivo research, $N$. sativa is known as a phytoestrogen [26]. N. sativa seeds contain active essential oil compounds, such as TQ, Dithymoquinone, Thymohydroquinone, Thymol, and alpha hederin ( $\alpha$-hederin). TQ, a component of $N$. sativa which is 
predicted to be responsible for estrogenic effects, with ER receptors. $N$. sativa extract at a concentration of $200 \mu \mathrm{g} / \mathrm{ml}$ increased the proliferation of $\mathrm{CHO}-\mathrm{K} 1$ cells and could reduce the expression of Cyclin $\mathrm{E}$ protein in $\mathrm{CHO}-\mathrm{K} 1$ cells. TQ as a model that represents one of the compounds contained in $N$. sativa extract can bind to ER receptors molecularly.

It can be concluded that the administration of TQ-rich $N$. sativa seed extract has anti-proliferative and pro-apoptotic effects on carcinoma cells, but is protective against healthy cells in the ovaries and other organs.

\section{Conclusion}

In this study, it was found that there is a trend that $N$. sativa is beneficial in protecting the ovaries from damage caused by CIS.

\section{Acknowledgment}

The authors gratefully acknowledge that this study is suported the Universitas Sumatera Utara We would also like to thank to all who contributed to this research.

\section{References}

1. Bray F, Ferlay J, Soerjomataram I, Siegel RL, Torre LA, Jemal A. Global cancer statistics 2018: GLOBOCAN estimates of incidence and mortality worldwide for 36 cancers in 185 countries. CA Cancer J Clin. 2018;68(6):394-424. https://doi. org/10.3322/caac. 21492

PMid:30207593

2. World Health Organization. Cancer insiden in Indonesia. Lyon, France: International Agency for Research on Cancer; 2020. p. 858.

3. National Cancer Institute. Cancer Statistic. Bethesda, Maryland: National Cancer Institute; 2020. https://doi.org/10.5152/ dir.2018.18102

4. Lumachi F. Current medical treatment of estrogen receptorpositive breast cancer. World J Biol Chem. 2015;6(3):231. PMid:26322178

5. Anderson RA, Mitchell RT, Kelsey TW, Spears N, Telfer EE, Wallace WH. Cancer treatment and gonadal function: Experimental and established strategies for fertility preservation in children and young adults. Lancet Diabetes Endocrinol. 2015;3(7):556-67. https://doi.org/10.1016/ s2213-8587(15)00039-x

PMid:25873571

6. Bildik G, Akin N, Senbabaoglu F, Sahin GN, Karahuseyinoglu S,
Ince U, et al. GnRH agonist leuprolide acetate does not confer any protection against ovarian damage induced by chemotherapy and radiation in vitro. Hum Reprod. 2015;30(12):2912-25. https://doi.org/10.1093/humrep/dev257

PMid:26466909

7. Yuksel A, Bildik G, Senbabaoglu F, Akin N, Arvas M, Unal F, et al. The magnitude of gonadotoxicity of chemotherapy drugs on ovarian follicles and granulosa cells varies depen ding upon the category of the drugs and the type of granulosa cells. Hum Reprod. 2015;30(12):2926-35. https://doi.org/10.1093/humrep/ dev256

PMid:26466914

8. Kim SY, Nair DM, Romero M, Serna VA, Koleske AJ, Woodruff TK, et al. Transient inhibition of p53 homologs protects ovarian function from two distinct apoptotic pathways triggered by anticancer therapies. Cell Death Differ. 2019;26(3):502-15. https://doi.org/10.1038/s41418-018-0151-2 PMid:29988075

9. Morgan S, Lopes F, Gourley C, Anderson RA, Spears N Cisplatin and doxorubicin induce distinct mechanisms of ovarian follicle loss; imatinib provides selective protection only against cisplatin. PLoS One. 2013;8(7):e70117. https://doi.org/10.1371/ journal.pone.0070117 PMid:23922929

10. Rossi V, Lispi M, Longobardi S, Mattei M, Di Rella F, Salustri A, et al. LH prevents cisplatin-induced apoptosis in oocytes and preserves female fertility in mouse. Cell Death Differ. 2017;24(1):72-82. https://doi.org/10.1038/cdd.2016.97 PMid:27689876

11. Nguyen QN, Zerafa N, Liew SH, Morgan FH, Strasser $A$ Scott CL, et al. Loss of PUMA protects the ovarian reserve during DNA-damaging chemotherapy and preserves fertility. Cell Death Dis. 2018;9(6):618. https://doi.org/10.1038/s41419-018-0633-7

12. Gonfloni S, Di Tella L, Caldarola S, Cannata SM, Klinger FG, Di Bartolomeo C, et al. Inhibition of the C-Abl-TAp63 pathway protects mouse oocytes from chemotherapy-induced death. Nat Med. 2009;15(10):1179-85. https://doi.org/10.1038/nm.2033 PMid:19783996

13. Spears N, Lopes F, Stefansdottir A, Rossi V, De Felici M, Anderson RA, et al. Ovarian damage from chemotherapy and current approaches to its protection. Hum Reprod Update. 2019;25(6):673-93. https://doi.org/10.1093/humupd/dmz027 PMid:31600388

14. Özcan P, Fıçıcıoğlu C, Kizilkale O, Yesiladali M, Tok OE, Ozkan F, et al. Can Coenzyme Q10 supplementation protect the ovarian reserve against oxidative damage? J Assist Reprod Genet. 2016;33(9):1223-30. https://doi.org/10.1007/ s10815-016-0751-z PMid:27255570

15. Taskin MI, Yay A, Adali E, Balcioglu E, Inceboz U. Protective effects of sildenafil citrate administration on cisplatin-induced ovarian damage in rats. Gynecol Endocrinol. 2015;31(4):272-7. https://doi.org/10.3109/09513590.2014.984679 PMid:25483005

16. Altuner D, Gulaboglu M, Yapca OE, Cetin N. The effect of mirtazapine on cisplatin-induced oxidative damage and infertility in rat ovaries. Sci World J. 2013;2013:327240. https://doi. org/10.1155/2013/327240

17. Assi MA, Abba Y, Abdulkhaleq LA, Hezmee MN, Haron AW, Yusof MS, et al. Effect of powdered seed of Nigella sativa administration on sub-chronic and chronic lead acetate induced hemato-biochemical and histopathological changes in Sprague Dawley rats. Comp Clin Pathol. 2018;27(3):705-16. https://doi. org/10.1007/s00580-018-2655-z

18. Aldossary SA. Review on pharmacology of cisplatin: Clinical 
use, toxicity and mechanism of resistance of cisplatin. Biomed Pharmacol J. 2019;12(1):7-15. https://doi.org/10.13005/ bpj/1608

19. Venegas C, García JA, Escames G, Ortiz F, López A, Doerrier C, et al. Extrapineal melatonin: Analysis of its subcellular distribution and daily fluctuations. J Pineal Res. 2012;52(2):217-27. https:// doi.org/10.1111/j.1600-079x.2011.00931.x

PMid:21884551

20. Abdulah N, Kouwagam AD, Andina AA. Anti-müllerian hormone and inhibin-B level profile in cervical cancer patients treated with paclitaxel and cisplatin combination. Bali Med J. 2014;3(2):73-7. https://doi.org/10.15562/bmj.v3i2.78

21. Yucebilgin MS, Terek MC, Ozsaran A, Akercan F, Zekioglu O, Isik E, et al. Effect of chemotherapy on primordial follicular reserve of rat: An animal model of premature ovarian failure and infertility. Aust N Z J Obstet Gynaecol. 2004;44(1):6-9. https:// doi.org/10.1111/j.1479-828x.2004.00143.x PMid: 15089860

22. Ismail M, Al-Naqeep G, Chan KW. Nigella sativa thymoquinonerich fraction greatly improves plasma antioxidant capacity and expression of antioxidant genes in hypercholesterolemic rats. Free Radic Biol Med. 2010;48(5):664-72. https://doi. org/10.1016/j.freeradbiomed.2009.12.002

PMid:20005291

23. Mohammed AE. Nigella sativa oil improves physiological parameters, oocyte quality after ovarian transplantation, and reproductive performance of female mice. Pak $\mathrm{J}$ Zool. 2019;51(6):2225-31. https://doi.org/10.17582/journal. pjz/2019.51.6.2225.2231

24. Mastuti S, Hadi DT, Chodidjah C. Nigella sativa seed extract ointment increasing the amount of healing fibroblast and collagen on Balb/Cmice. Sains Med. 2017;8(1):15. https://doi. org/10.26532/sainsmed.v8i1.1006

25. Ganji-Harsini S, Khazaei M, Rashidi Z, Ghanbari A Thymoquinone could increase the efficacy of tamoxifen induced apoptosis in human breast cancer cells: An in vitro study. Cell J. 2016;18(2):245-54. PMid:27540530

26. Parhizkar S, Latiff LA, Parsa A. Effect of Nigella sativa on reproductive system in experimental. Avicenna J Phytomed. 2016;6(1):95-103.

PMid:27247926 